\title{
STABILITAS FISIK DAN AKTIVITAS ANTIOKSIDAN SEDIAAN GEL BERBAHAN AKTIF EKSTRAK ETANOL DAUN MIANA (COLEUS ANTROPURPUREUS BENT.)
}

\author{
Mardiatul Ulfah, Aditya Fridayanti*, Muhammad Amir Masruhim \\ Laboratorium Penelitian dan Pengembangan FARMAKA TROPIS, Fakultas Farmasi, \\ Universitas Mulawarman, Samarinda, Kalimantan Timur \\ email: aditya@farmasi.unmul.ac.id
}

\begin{abstract}
Miana (Coleus antropurpureus Bent) leaves have been studied and examined to have excellent antioxidant activity. This research aims to determine the stability and activity of antioxidant gel which contain Miana (Coleus antropurpureus Bent) leaves extracted with ethanol. The gel formulated by using $5 \%$ HPMC as the base. The concentration of miana leaves extract those examined are $0 \%$ for the negative control, 0,5\%,1\% and 1,5\%, made in gel dosage form. The test were carried out with accelerated storage cycling test methods for 4 cycles ( 4 days for each cycle), incluiding physical stability test (organoleptic observations, $p H$ measurement and viscosity measurement) and percent of antioxidant activity test with DPPH method that measured, absorbances using UV-Visible spectrophotometer. The percent of antioxidant activity of gel contain Miana (Coleus antropurpureus Bent) leaves extract at 1\% concentration showed a stable activity during room temperature storage and in freeze thaw storage. In stability evaluation test, gel contained Miana (Coleus antropurpureus Bent) leaves extract at 0,5\% concentration obtained pH stability with no significant change during storage in both of room temperature and freeze thaw. Furthermore, the gel at concentrations of 0,5\% and 1,5\% had a stability of viscosity room temperature storage and also in freeze thaw storage.
\end{abstract}

Keywords: Gel, antioxidants, miana leaf

\begin{abstract}
Abstrak
Daun miana (Coleus antropurpureus Bent) telah diteliti dan memiliki aktivitas antioksidan yang sangat baik. Penelitian ini bertujuan untuk mengetahui stabilitas dan aktivitas gel antioksidan ekstrak daun miana (Coleus antropurpureus Bent). Penelitian dilakukan dengan cara ekstraksi daun miana (Coleus antropurpureus Bent) menggunakan pelarut etanol. Formulasi sediaan gel menggunakan basis HPMC $5 \%$. Konsentrasi ekstrak yang digunaan adalah $0 \%$ untuk kontrol negatif, $0,5 \%, 1 \%$ dan $1,5 \%$ yang dibuat dalam bentuk sediaan gel. Uji dilakukan dengan metode penyimpanan dipercepat cycling test selama 4 siklus ( 1 siklus selama 4 hari) meliputi uji stabilitas fisik berupa pengamatan organoleptis, pengukuran $\mathrm{pH}$ dan pengukuran visikositas, serta pengujian persen aktivitas antioksidan dengan metode DPPH dengan cara mengukur besarnya absorbansi pada alat spektrofotometer $U V$-Visible. Hasil persen aktivitas antioksidan sediaan gel ekstrak daun miana (Coleus antropurpureus Bent) pada konsentrasi $1 \%$ memiliki aktivitas yang stabil pada penyimpanan suhu kamar maupun penyimpanan freeze thaw. Hasil yang diperoleh dari evaluasi stabilitas, sediaan gel pada konsentrasi ekstrak $0,5 \%$ memiliki kestabilaan $\mathrm{pH}$
\end{abstract}


pada penyimpanan freeze thaw. Sediaan gel pada konsentrasi ekstrak 0,5\% dan 1,5\% memiliki kestabilaan viskositas pada penyimpanan suhu kamar dan freeze thaw.

Kata Kunci: Gel, antioksidan, daun miana

\section{PENDAHULUAN}

Eksplorasi tumbuhan saat ini bukan hanya untuk pengobatan tradisional, beberapa studi di dunia telah diterima dan dikembangkan lebih lanjut untuk menelaah fungsinya sebagai bahan dalam pembuatan kosmetik. Jumlah produk kosmetik yang mengandung ekstrak tumbuhan meningkat tajam yang disebabkan oleh efek terapetik, aroma dan opini bahwa ekstrak tumbuhan lebih aman dibanding dengan senyawa sintetis (Corazza dkk., 2009 dan Chen dkk., 2011).

Kulit merupakan organ paling luar yang menutupi permukaan tubuh dan paling sering terpapar matahari. Indonesia merupakan negara tropis dengan paparan sinar matahari yang melimpah sehingga beresiko tinggi terhadap kerusakan kulit. Paparan sinar UV menyebabkan terbentuknya radikal bebas dari ROS yang merupakan molekul tidak stabil. Selain paparan sinar matahari, radikal bebas juga diperoleh dari aktivitas kehidupan sehari-hari seperti asap rokok, makanan yang digoreng dan dibakar, asap kendaraan bermotor, obat-obat tertentu, racun dan polusi udara.

Radikal bebas akan berikatan dengan komponen sel untuk menjadi stabil, sehingga akan merusak komponen sel seperti lemak, protein dan asam nukleat. Kerusakan komponen sel akan menyebabkan penuaan dini pada kulit yang ditandai dengan kering, keriput dan kusam. Untuk mencegah terjadinya hal tersebut diperlukan suatu sediaan kosmetik yang mampu mencegah penuaan dini (Elsne dkk, 2000). Sediaan-sediaan yang dimaksud adalah sediaan bersifat antioksidan yang dapat meredam senyawa radikal bebas.

Penelitian aktivitas gel antioksidan di Indonesia juga telah dilakukan, beberapa diantaranya yakni Angela (2012) meneliti aktivitas antioksidan dan stabilitas fisik gel antiaging yang mengandung ekstrak air kentang kuning. Hapsari (2012) meneliti formulasi dan evaluasi antioksidan dari gel ekstrak etanol Pleuretus ostreatus. Penelitian-penelitian tersebut diatas menjelaskan bahwa tumbuhan yang memiliki efek antioksidan, beberapa diantaranya memiliki stabilitas dan aktivitas dalam bentuk sediaan gel antioksidan.

Saat ini, belum ada penelitian ilmiah daun miana (Coleus antropurpureus Bent) diformulasikan dalam sediaan gel antioksidan. Sehingga peneliti tertarik untuk meneliti stabilitas dan persen aktivitas sediaan gel antioksidan daun miana (Coleus antropurpureus Bent) yang sebelumnya telah diteliti aktivitas antioksidannya dan menunjukkan nilai $\mathrm{IC}_{50}$ yang kuat $(<100 \mathrm{ppm})$, dengan harapan penelitian ini dapat dikembangkan lebih luas lagi seperti pembuatan kosmetik lainnya. Persen aktivitas antioksidan didapat dengan mengukur absorbansi sampel menggunakan alat spektrofotometer $U V$-Visible.

\section{METODE PENELITIAN \\ Bahan}

Bahan yang diteliti adalah simplisia daun sumpit. Pelarut yang digunakan untuk ekstraksi adalah etanol, air suling sebagai pelarut pembuatan gel. HPMC, propilenglikol, metil paraben untuk pembuatan sediaan gel, pereaksi DPPH untuk pengujian antioksidan.

\section{Peralatan}

Peralatan yang digunakan dalam penelitian ini meliputi alat-alat gelas, bejana maserasi, rotary evaporator (büchi rotavapor R-200), timbangan analitik (Mettler toledo AL204), autoklaf (All American), oven (Bio Concept Froilabo ${ }^{\circledR}$ ), Sentrifuge (PLC Series 
$\left.K^{\circledR}\right)$ Spektrofotometer $U V$-Visible (HALO DB-205 Dynamica ${ }^{\circledR}$ ), pH-meter (370 pH-meter Jenway $\left.^{\circledR}\right)$, Viskometer $\left(\right.$ Rheosys $\left.^{\circledR}\right)$ dan alat penunjang lainnya.

\section{Prosedur}

\section{Ekstraksi}

Simplisia kering dimasukkan ke dalam wadah kaca, kemudian direndam dengan pelarut etanol selama kurang lebih $3 \times 24$ jam. Disaring pelarut hasil ekstraksi dan ditampung ke dalam wadah kaca, kemudian sisa simplisia kering daun miana kembali direndam dengan pelarut etanol, diulangi hingga sisa pelarut hasil ekstraksi. Dilakukan penguapan pelarut etanol ekstrak daun miana menggunakan rotary evaporator. Setelah itu, dikeringkan di water bath untuk mendapatkan ekstrak etanol.

\section{Pembuatan Formula Gel}

Pembuatani sediaan antioksidan bentuk gel menggunakan HPMC sebagai basis. Pada penelitian ini akan dibuat formula sediaan gel dengan 3 konsentrasi ekstak etanol daun miana. Cara pembuatan: HPMC dikembangkan dengan air suling sebanyak 10x jumlah HPMC sedikit demi sedikit lalu distirer dengan kecepatan $30 \mathrm{rpm}$ hingga terbentuk massa gel. Metil paraben dilarutkan dalam $2 \mathrm{~mL}$ propilenglikol pada suhu $70^{\circ} \mathrm{C}$. Ditambahkan dengan metil paraben yang telah dilarutkan dalam propilenglikol ke dalam HPMC dan ditambahkan larutan ekstrak, lalu ditambahkan air suling hingga $60 \mathrm{~mL}$ lalu distirer hingga homogen.

\section{Pengujian Sediaan Gel}

a. Pengujian Organoleptik

Pengamatan dilihat secara langsung bau, warna dan konsistensi dari gel yang dibuat

b. Pengujian Persen Aktivitas Antioksidan Gel

Persiapan pengujian aktivitas antioksidan gel meliputi penyiapan larutan DPPH 40 ppm, pembuatan larutan sampel gel dan pengujian absorbansi. 2 mL larutan sampel gel ditambahkan dengan $2 \mathrm{~mL}$ larutan DPPH, dihomogenkan dan dibiarkan ditempat gelap pada suhu amar selama 30 menit. Kemudian diukur absorbansinya pada panjang gelombang tertentu dan dihitung persen aktivitas antioksidan (\% AA).

c. Pengujian $\mathrm{pH}$

Penentuan $\mathrm{pH}$ sediaan dilakukan dengan menggunakan $\mathrm{pH}$-meter yang dicelupkan ke dalam sampel. Setelah tercelup sempurna, $\mathrm{pH}$-meter tersebut akan memunculkan angka yang menunjukkan nilai $\mathrm{pH}$ sediaan gel.

d. Pengujian Viskositas

Penentuan viskositas sediaan menggunakan alat viskometer dengan spindle cone and plate 5/30 $\mathrm{mm}$ dengan kecepatan $10 \mathrm{rpm}$ yang telah dimasukkan sediaan gel sebanyak 1 gram.

\section{HASIL DAN PEMBAHASAN}

Formula dibuat 3 konsentrasi yaitu 0,5\%, $1 \%$ dan 1,5\%. Selain itu, kontrol negatif sebagai pembanding yang hanya mengandung basis gel. Peneliti menggunakan HPMC sebagai gelling agent. Metil paraben efektif pada kisaran $\mathrm{pH}$ yang luas dan memiliki aktivitas anti mikroba yang kuat. Propilen glikol berfungsi sebagai pelarut metil paraben.

Mekanisme pembentukan gel oleh HPMC ini disebabkan adanya interaksi antara polimer dengan pelarut atau terjadi penggabungan antara molekul polimer yang menyebabkan jarak antara partikel menjadi kecil dan terbentuk ikatan silang antar molekul akan mengurangi mobilitas pelarut dan terbentuk massa gel. Formulasi gel dapat dilihat pada Tabel 1. 
Tabel 1. Rancangan formula sediaan Gel Ekstrak Etanol Daun Miana

\begin{tabular}{lcccc}
\hline \multirow{2}{*}{ Bahan } & \multicolumn{4}{c}{ Formula } \\
\cline { 2 - 5 } & Kontrol negatif & 1 & 2 & 3 \\
\hline Ekstrak & - & $0,5 \%$ & $1 \%$ & $1,5 \%$ \\
HPMC & $5 \%$ & $5 \%$ & $5 \%$ & $5 \%$ \\
Metil Paraben & $0,5 \%$ & $0,5 \%$ & $0,5 \%$ & $0,5 \%$ \\
Propilenglikol & $2 \mathrm{~mL}$ & $2 \mathrm{~mL}$ & $2 \mathrm{~mL}$ & $2 \mathrm{~mL}$ \\
Air suling untuk HPMC & $30 \mathrm{~mL}$ & $30 \mathrm{~mL}$ & $30 \mathrm{~mL}$ & $30 \mathrm{~mL}$ \\
Ai suling ad & $60 \mathrm{~mL}$ & $60 \mathrm{~mL}$ & $60 \mathrm{~mL}$ & $60 \mathrm{~mL}$ \\
\hline
\end{tabular}

\section{Uji Persen Aktivitas}

DPPH umum digunakan sebagai substrat karena sifatnya yang stabil dalam bentuk radial bebas, sensitif, cepat dan merupakan uji yang sederhana (Bozin dkk., 2008). Pengujian aktivitas antioksidan digunakan pelarut etanol, karena etanol tidak mempengaruhi dalam reaksi antara sampel uji sebagai antioksidan dengan DPPH sebagai radikal bebas (Molyneux, 2004 dan Marxen, 2007).

Data rata-rata persen aktivitas antioksidan dari 3 konsentrasi pada penyimpanan suhu kamar dan freeze thaw, yaitu sebagai berikut:

Tabel 2. Hasil Perlakuan Uji Persen aktivitas antioksidan Sediaan Gel Ekstrak Etanol Daun Miana Pada Suhu Kamar dan Freeze Thaw

\begin{tabular}{ccccc}
\hline $\begin{array}{c}\text { Suhu } \\
\text { Penyimpanan }\end{array}$ & Siklus & \multicolumn{3}{c}{ Aktivitas Antioksidan $(\%) \pm$ Standar Deviasi } \\
\cline { 2 - 5 } & & $0,5 \%$ & $1 \%$ & $1,5 \%$ \\
\hline \multirow{5}{*}{ Suhu Kamar } & S0 & $86,728 \pm 0,176$ & $85,232 \pm 2,825$ & $82,931 \pm 0,351$ \\
& S1 & $74,094 \pm 0,320$ & $85,255 \pm 0,000$ & $81,707 \pm 0,111$ \\
& S2 & $72,050 \pm 0,325$ & $81,629 \pm 0,384$ & $78,984 \pm 0,074$ \\
& S3 & $65,490 \pm 0,445$ & $86,392 \pm 0,068$ & $85,569 \pm 0,136$ \\
& S4 & $72,144 \pm 0,342$ & $87,066 \pm 0,065$ & $85,935 \pm 0,173$ \\
\hline \multirow{5}{*}{ Frezee Thaw } & S0 & $86,728 \pm 0,173$ & $85,232 \pm 2,825$ & $82,931 \pm 0,351$ \\
& S1 & $76,736 \pm 0,252$ & $87,568 \pm 0,109$ & $81,570 \pm 0,000$ \\
& S2 & $77,442 \pm 0,347$ & $87,069 \pm 0,108$ & $84,411 \pm 0,125$ \\
& S3 & $71,428 \pm 0,367$ & $81,693 \pm 0,106$ & $79,682 \pm 0,001$ \\
& S4 & $64,958 \pm 1,602$ & $88,375 \pm 0,058$ & $84,288 \pm 0,058$ \\
\hline
\end{tabular}

Dari data pada Tabel 2. Dapat dibuat grafik hubungan suhu penyimpanan dan konsentrasi terhadap aktivitas antioksidan (Gambar 1.) yang diperoleh dan diolah menggunakan statistik. 


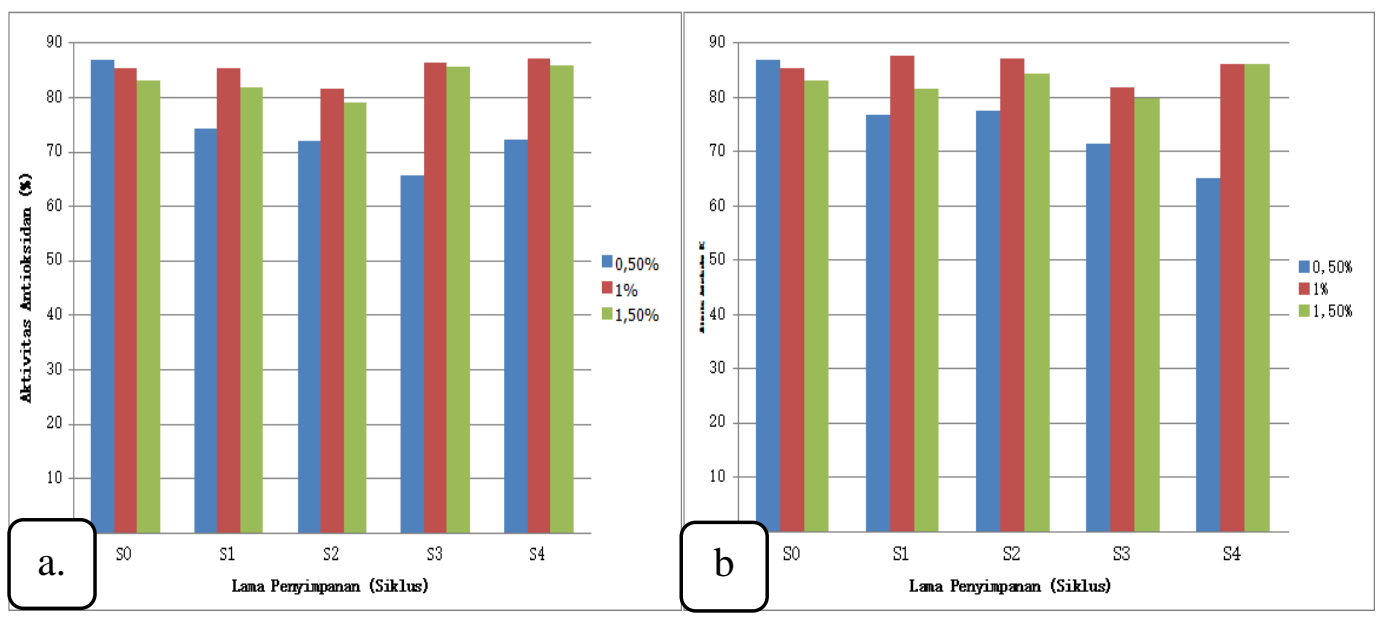

Gambar 1. Grafik Hubungan Siklus dengan \% Aktivitas Antioksidan Stabilitas Gel Ekstrak Daun Miana pada (a) Suhu Kamar (b) Freeze thaw

Hasil pada konsentrasi 0,5\% dan 1,5\% mengalami kenaikan persen aktivitas hal ini membuktikan terdapat perbedaan yang signifikan pada tiap siklus penyimpanan, baik pada suhu kamar maupun freeze thaw. Namun, pada konsentrasi $1 \%$ tidak terjadi kenaikan ataupun penurunan aktivitas antioksidan yang signifikan. Hal ini menunjukkan, pada konsentrasi $1 \%$ cukup stabil untuk mempertahankan aktivitas antioksidan sediaan gel ekstrak. Penurunan absorbansi setelah penambahan sediaan gel terjadi karena adanya senyawa antioksidan dari ekstrak yang mendonorkan $\mathrm{H}^{+}$pada DPPH, sehingga mengubah radikal bebas DPPH yang berwarna ungu menjadi senyawa non radikal DPP Hidrazin yang berwarna kuning pucat atau warna ungunya hilang (Molyneux, 2004).

\section{Uji Stabilitas}

Pengujian sifat fisik gel yang telah dibuat meliputi uji organoleptis, uji $\mathrm{pH}$ dan uji viskositas setiap 4 hari (1 siklus) selama 4 siklus pada kondisi suhu penyimpanan yang berbeda yaitu pada suhu kamar dan freeze thaw.

a. Organoleptis

Data hasil uji organoleptis gel antioksidan dari gel basis dan 3 konsentrasi pada penyimpanan suhu kamar dan freeze thaw selama 4 siklus, yaitu sebagai berikut:

Tabel 3. Hasil Perlakuan Uji Organoleptik Sediaan Gel Ekstrak Etanol Daun Miana Pada berbagai konsentrasi selama 4 siklus

\begin{tabular}{ccccll}
\hline Siklus & Suhu & Konsentrasi & Bau & \multicolumn{1}{c}{ Warna } & \multicolumn{1}{c}{ Konsistensi } \\
\hline 0 & Kamar & Basis & Khas & Bening & Agak lengket \\
& $0,5 \%$ & Khas & Merah coklat & Lengket \\
& & $1 \%$ & Khas & Coklat tua & Lebih lengket \\
& & $1,5 \%$ & Khas & Coklat tua pekat & Lebih lengket \\
\cline { 3 - 6 } & Freeze Thaw & Basis & Khas & Bening & Agak lengket \\
& $0,5 \%$ & Khas & Merah coklat & Lengket \\
& $1 \%$ & Khas & Coklat tua & Lebih lengket \\
& & $1,5 \%$ & Khas & Coklat tua pekat & Lebih lengket \\
\hline 1 & Kamar & Basis & Khas & Bening & Agak lengket \\
& & $0,5 \%$ & Khas & Merah coklat & Lengket \\
& & $1 \%$ & Khas & Coklat tua & Lebih lengket \\
\hline
\end{tabular}




\begin{tabular}{cccll}
\hline & $1,5 \%$ & Khas & Coklat tua pekat & Lebih lengket \\
\hline Freeze Thaw & Basis & Khas & Bening & Agak lengket \\
& $0,5 \%$ & Khas & Merah coklat & Lengket \\
& $1 \%$ & Khas & Coklat tua & Lebih lengket \\
& $1,5 \%$ & Khas & Coklat tua pekat & Lebih lengket \\
\hline Kamar & Basis & Khas & Bening & Agak lengket \\
& $0,5 \%$ & Khas & Merah coklat & Lengket \\
& $1 \%$ & Khas & Coklat tua & Lebih lengket \\
& $1,5 \%$ & Khas & Coklat tua pekat & Lebih lengket \\
\hline Freeze Thaw & Basis & Khas & Bening & Agak lengket \\
& $0,5 \%$ & Khas & Merah coklat & Lengket \\
& $1 \%$ & Khas & Coklat tua & Lebih lengket \\
& $1,5 \%$ & Khas & Coklat tua pekat & Lebih lengket \\
\hline & Basis & Khas & Bening & Agak lengket \\
& $0,5 \%$ & Khas & Merah coklat & Lengket \\
& $1 \%$ & Khas & Coklat tua & Lebih lengket \\
& $1,5 \%$ & Khas & Coklat tua pekat & Lebih lengket \\
\hline Kamar & Basis & Khas & Bening & Agak lengket \\
& $0,5 \%$ & Khas & Merah coklat & Lengket \\
& $1 \%$ & Khas & Coklat tua & Lebih lengket \\
& $1,5 \%$ & Khas & Coklat tua pekat & Lebih lengket \\
\hline Freeze Thaw & Basis & Khas & Bening & Agak lengket \\
& $0,5 \%$ & Khas & Merah coklat & Lengket \\
& $1 \%$ & Khas & Coklat tua & Lebih lengket \\
& $1,5 \%$ & Khas & Coklat tua pekat & Lebih lengket \\
\hline & Basis & Khas & Bening & Agak lengket \\
& $0,5 \%$ & Khas & Merah coklat & Lengket \\
& $1 \%$ & Khas & Coklat tua & Lebih lengket \\
& $1,5 \%$ & Khas & Coklat tua pekat & Lebih lengket \\
\hline & & & &
\end{tabular}

Berdasarkan data hasil pengamatan uji organoleptis (Tabel 3.) diketahui bahwa sediaan gel antioksidan tanpa ataupun dengan penambahan ekstrak daun miana (Coleus antropurpureus Bent.) tidak mengalami perubahan bau, warna maupun konsistensi. Evaluasi gel menunjukan hasil yang sama ketika dilanjutkan pada siklus selanjutnya, sehingga semua sediaan memenuhi kriteria untuk dilanjutkan pengujian stabilitas $\mathrm{pH}$, viskositas dan aktivitas antioksidan.

b. $\mathrm{pH}$

Data hasil pengujiian $\mathrm{pH}$ gel antioksidan dari gel basis dan 3 konsentrasi pada penyimpanan suhu kamar dan freeze thaw selama 4 siklus, yaitu sebagai berikut:

Tabel 4. Hasil Perlakuan Uji pH Sediaan Gel Ekstrak Etanol Daun Miana Pada berbagai konsentrasi selama 4 siklus

\begin{tabular}{cccccc}
\hline \multirow{2}{*}{$\begin{array}{c}\text { Suhu } \\
\text { Penyimpanan }\end{array}$} & \multirow{2}{*}{ Siklus } & \multicolumn{4}{c}{$\mathrm{pH} \pm$ Standar Deviasi } \\
\cline { 3 - 6 } & & Basis & $0,5 \%$ & $1 \%$ & $1,5 \%$ \\
\hline Suhu Kamar & S0 & $6,117 \pm 0,015$ & $5,947 \pm 0,032$ & $5,980 \pm 0,030$ & $5,820 \pm 0,010$ \\
& S1 & $6,030 \pm 0,017$ & $5,780 \pm 0,026$ & $5,720 \pm 0,035$ & $5,690 \pm 0,017$ \\
& S2 & $6,027 \pm 0,015$ & $5,817 \pm 0,021$ & $5,767 \pm 0,012$ & $5,773 \pm 0,006$
\end{tabular}




\begin{tabular}{llllll} 
& S3 & $5,937 \pm 0,029$ & $5,580 \pm 0,000$ & $5,580 \pm 0,000$ & $5,570 \pm 0,026$ \\
& S4 & $5,943 \pm 0,059$ & $5,547 \pm 0,038$ & $5,487 \pm 0,012$ & $5,503 \pm 0,012$ \\
\hline Frezee Thaw & S0 & $6,117 \pm 0,015$ & $5,947 \pm 0,032$ & $5,980 \pm 0,030$ & $5,820 \pm 0,010$ \\
& S1 & $5,913 \pm 0,006$ & $5,650 \pm 0,026$ & $5,637 \pm 0,015$ & $5,627 \pm 0,006$ \\
& S2 & $6,030 \pm 0,010$ & $5,700 \pm 0,010$ & $5,647 \pm 0,021$ & $5,617 \pm 0,029$ \\
& S3 & $5,963 \pm 0,049$ & $5,570 \pm 0,010$ & $5,540 \pm 0,000$ & $5,563 \pm 0,006$ \\
& S4 & $6,127 \pm 0,012$ & $5,977 \pm 0,618$ & $5,590 \pm 0,010$ & $5,573 \pm 0,021$ \\
\hline
\end{tabular}

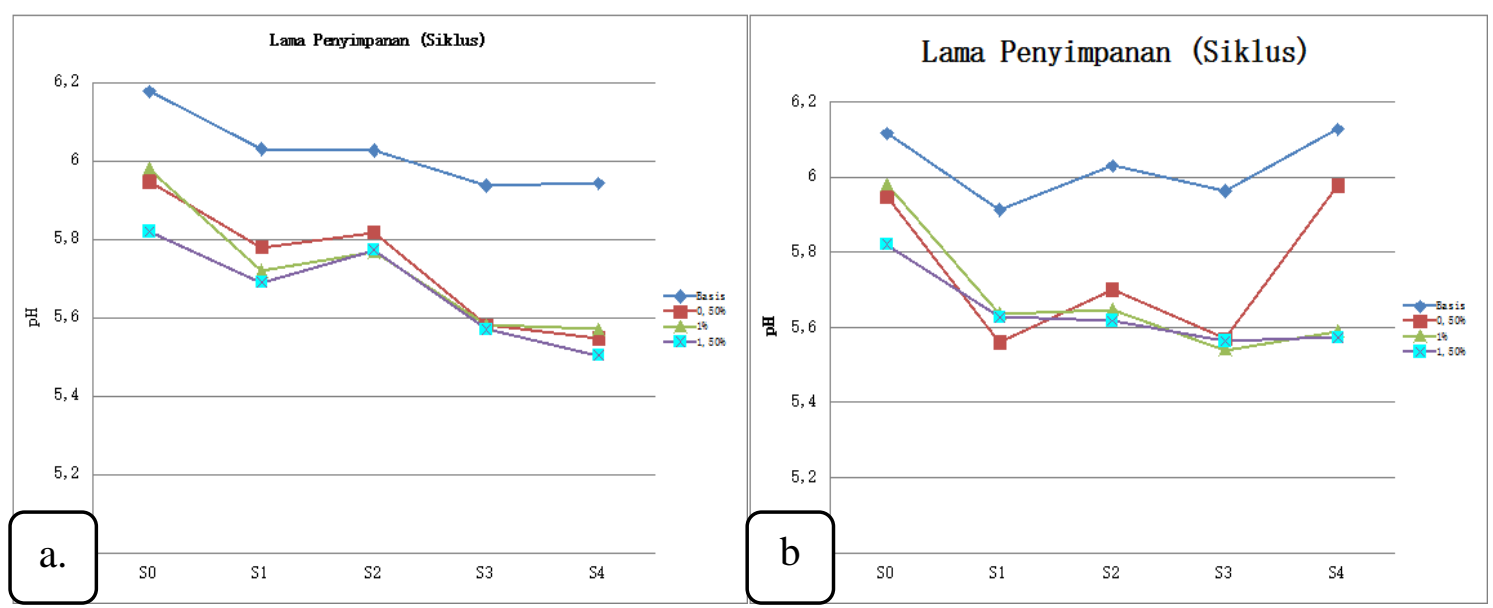

Gambar 2. Grafik Hubungan Siklus dengan pH Stabilitas Sediaan Gel Ekstrak Daun Miana Pada (a) Suhu Kamar (b) Freeze thaw

Uji statistik pada suhu kamar, gel basis tanpa ekstrak tidak menunjukkan perbedaan yang signifikan antara rata-rata nilai $\mathrm{pH}$, karena diperoleh nilai signifikan $>0,05$. Namun, pada gel ekstrak dengan konsentrasi 0,5\%,1\% dan 1,5\% menunjukkan perbedaan yang signifikan antara rata-rata aktivitas antioksidan dan penyimpanan siklus. Pada freeze thaw, gel basis tanpa ekstrak dan gel ekstrak 0,5\% tidak menunjukkan perbedaan yang signifikan antara rata-rata nilai $\mathrm{pH}$. Namun, pada gel ekstrak dengan konsentrasi $1 \%$ dan $1,5 \%$ menunjukkan perbedaan yang signifikan.

Evaluasi $\mathrm{pH}$ pada sediaan gel ekstrak daun miana (Coleus antropurpureus Bent) selama 4 siklus menunjukkan adanya perubahan dengan bertambahnya waktu penyimpanan. Secara umum, perubahan ini disebabkan terjadinya hidrolisis senyawa yang bersifat asam pada sediaan. Namun, nilai $\mathrm{pH}$ ini masih sesuai dengan kriteria $\mathrm{pH}$ yang aman untuk kulit yaitu antara 4,2-6,5. Dari hasil evaluasi $\mathrm{pH}$ dapat disimpulkan bahwa sediaan gel yang didapat cukup stabil, karena perubahan yang terjadi setelah peyimpanan tidak terlalu signifikan.

c. Viskositas

Data hasil pengujiian viskositas gel antioksidan dari gel basis dan 3 konsentrasi pada penyimpanan suhu kamar dan freeze thaw selama 4 siklus, yaitu sebagai berikut: 
Tabel 5. Hasil Uji Viskositas Sediaan Gel Ekstrak Etanol Daun Miana Pada

berbagai konsentrasi selama 4 siklus

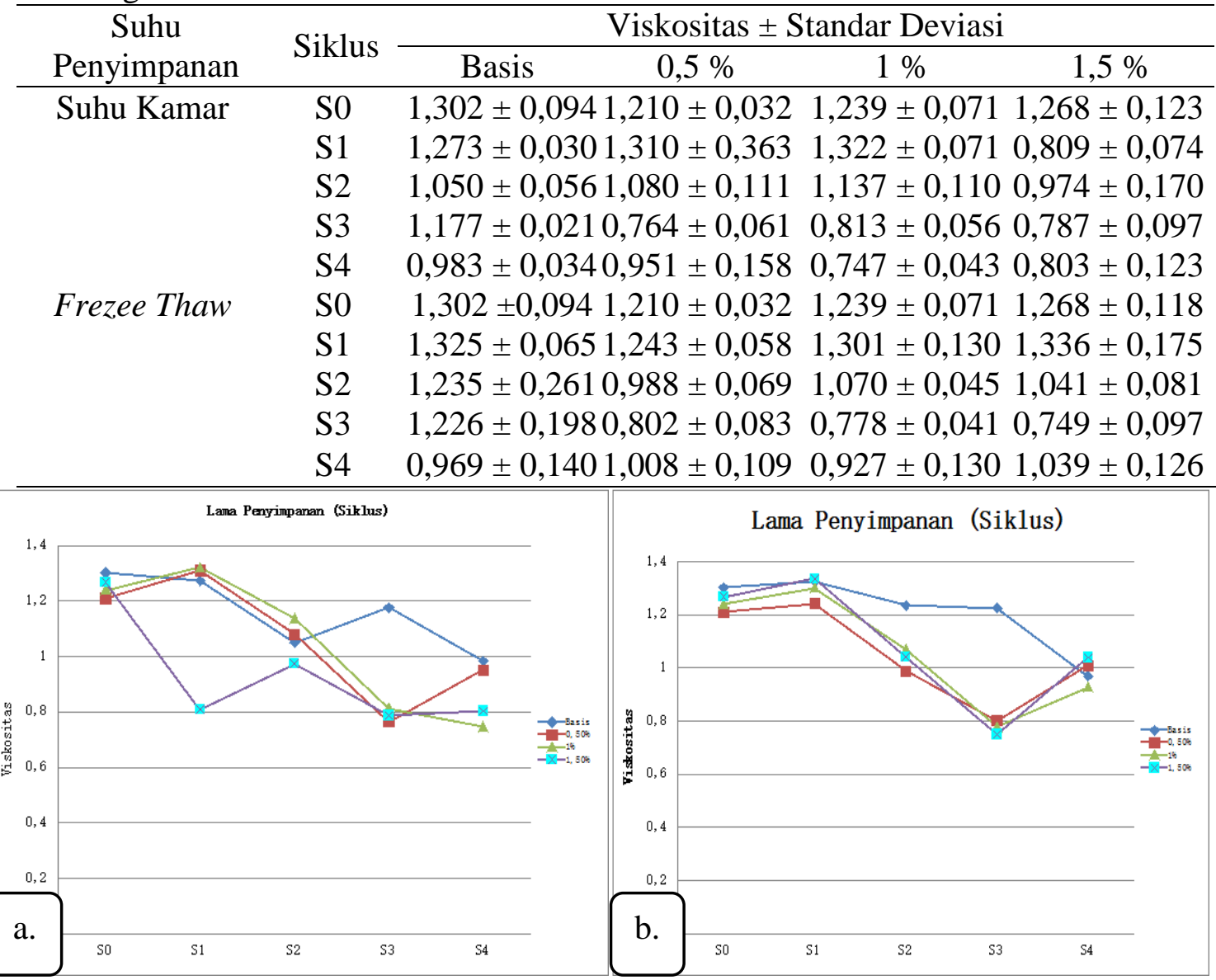

Gambar 3. Grafik Hubungan Sikus dengan Viskositas Stabilitas Sediaan Gel Ekstrak Daun Miana Pada (a) Suhu Kamar (b) Freeze thaw

Uji t-test pada suhu kamar, gel basis tanpa ekstrak dan gel ekstrak $1 \%$ menunjukkan perbedaan yang signifikan antara rata-rata nilai $\mathrm{pH}$. Namun, pada gel ekstrak dengan konsentrasi $0,5 \%$ dan $1,5 \%$ menunjukkan tidak ada perbedaan yang signifikan antara rata-rata aktivitas antioksidan dan penyimpanan siklus. Uji statistik pada freeze thaw, gel basis tanpa ekstrak, gel ekstrak $0,5 \%$ dan $1 \%$ menunjukkan perbedaan yang signifikan antara rata-rata nilai pH.Gel ekstrak dengan konsentrasi 1,5\% menunjukkan tidak ada perbedaan yang signifikan

Penurunan viskositas dapat disebabkan oleh kondisi lingkungan penyimpanan seperti temperatur, cahaya dan kelembaban udara. Kemasan yang kurang kedap dapat menyebabkan gel menyerap uap air dari luar, sehingga menambah volume air dalam gel (Kumesan dkk., 2013).

\section{KESIMPULAN}

Berdasarkan penelitian yang telah dilakukan, maka dapat disimpulkan bahwa aktivitas sediaan gel ekstrak etanol daun miana pada konsentrasi $1 \%$ lebih stabil daripada sediaan gel ekstrak etanol daun miana pada konsentrasi $0,5 \%$ dan $1,5 \%$ selama penyimpanan suhu kamar dan freeze thaw karena tidak mengalami perubahan secara signifikan. Berdasarkan lama waktu penyimpanan pada suhu kamar dan freeze thaw ketiga sediaan stabil secara organoleptis dan viskositas, hanya $\mathrm{pH}$ sediaan gel ekstrak etanol daun miana pada 
konsentrasi $1 \%$ dan $1,5 \%$ yang memiliki pergeseran $\mathrm{pH}$ yang cukup besar tetapi masih masuk memenuhi persyaratan $\mathrm{pH}$ sediaan gel pada kulit.

\section{SARAN}

Berdasarkan penelitian yang telah dilakukan, maka disarankan untuk melakukan pengujian aktivitas antioksidan ekstrak daun mana varietas yang lain unuk membandingkan potensi antioksidan dari berbagai jenis varietas tanaman miana, serta penelitan lebih lanjut dengan menggunakan basis gel yang lain agar untuk membandingkan stabilitas dan aktivitas sediaan daun miana

\section{DAFTAR PUSTAKA}

1. Chen, Y.F., Roan HY., Lii CK., Huang YC., Wang TS.. 2011. Relationship Between Antioxidant and Antiglycation Ability of Saponins, Polyphenol and Polysaccharides In Chinese Herbal Medicines Used To Treat Diabetes. Journal of Medicinal Plants Research, 5(11): 2322-2331.

2. Corazza, M., Borghi A., Lauriola MM., Virgili A.. 2009. Use to Topical Herbal Remedies and Cosmetics: A Questionnaire-Based Investigation In Dermalogy Out Patient. Journal Europa Academy Dermatoogy Venecool, 23(1): 1298-1303.

3. Elsne, P. dan Howard I.M.. 2000. Cosmeceuticals Drug vs Cosmetics. Marcel Dekker Inc. New York.

4. Kumesan, Yuni Arista N., Paulina V. Y. Yamlean, Hamidah S. Supriati. 2013. Formulasi dan Uji Aktivitas Gel Antijerawat Ekstrak Umbi Bakung (Crinum asiaticum L.) Terhadap Bakteri Staphylococcus aureus Secara In Vitro. Jurnal Ilmiah Farmasi Pharmacon UNSRAT Vol. 2 No. 2. Unsrat. Manado.

5. Molyneux, P.. 2004. The use of the stable free radical diphenylpicrylhydrazyl (DPPH) for estimating antioxidant activity. Songklanakarin Journal Science Technology. 26 (2) 